\title{
Conceptualising the 'Perfect' Family in Late Nineteenth-Century Philanthropic Institutions
}

\author{
Steven J. Taylor
}

\section{Overview}

The cult of domesticity and the Victorian science of Eugenics have done much to emphasise the importance of blood ties in linking families together. In reality, however, many nineteenth-century children were brought up by people other than their biological parents. Throughout this volume we have seen how new kinship and fictive kinship networks could be created by combining existing groups into reconfigured families. There is also plenty of evidence of the provision of broadly conceived foster care provided by relatives, family friends, and other individuals. ${ }^{1}$ Thus, as Carol Beardmore shows in her chapter for this volume, Edward Wrench took into his own home, his wife's nieces and cared for them alongside his own children over a period of many years. The number of children brought up outside Peter Laslett's nuclear unit is hard to estimate. George Behlmer perhaps gets closest to providing the scale of fractured families through his suggestion that of those living

\footnotetext{
S. J. Taylor $(\bowtie)$

University of Leicester, Leicester, UK e-mail: sjt48@le.ac.uk

(C) The Author(s) 2019

C. Beardmore et al. (eds.), Family Life in Britain, 1650-1910, https://doi.org/10.1007/978-3-030-04855-6_8
} 
in Lancashire and East London, around one-third would have lost one parent (and $10 \%$ both) by the age of fifteen. ${ }^{2}$ It is therefore unsurprising that step-parenting, fostering, and even single parenting were major topics of discussion during the Victorian period. More widely, Victorian society collectively worried (much as modern commentators do) about the fragility of family units, with 'nomadic husbands' who moved from family to family, alcoholic parents, wandering wives, and working-parents all featuring in social investigations from the $1860 \mathrm{~s}^{3}$

At the core of these contemporary observations and concerns was an underlying sense that children were being failed by family and kin and that such failure might have fundamental consequences for the social fabric of a future Britain. ${ }^{4}$ Fears about national efficiency and potential decline loomed large. ${ }^{5}$ The active response to such fears can be seen in the rise of Victorian institutions and charities which were tasked (by donors) or tasked themselves with the identification, support, and sometimes removal of vulnerable children in/from their family context. ${ }^{6}$ This is not, of course, a new observation, but new opportunities to analyse the records of some of these bodies offer us a way to rethink the nature, shape, and meaning of the working-class family in the Victorian period. ${ }^{7}$ This chapter, then, explores how middling and elite philanthropists conceived and constructed the poorest of working-class families. More specifically the chapter asks the questions: what were the characteristics of perceived problem families? To what extent did ideas of the 'perfect' family influence middle- and working-class attitudes towards children? How did philanthropic reformers attempt to reconceptualise the working-family? And were these redefinitions and reconceptualisations resisted? The answers to these questions are complex but bring the nascent middle-class construct of nineteenth-century family life into view and allow evaluation of how working-people reacted to these impositions. Through a close case study of one of the great charitable institutions of the late nineteenth century-the Waifs and Strays Society (hereafter WSS) - it is possible to bring new perspectives to a set of familiar but unresolved questions.

Founded in 1881 by Edward de Montjoie Rudolf, the WSS developed as a singular element of the late nineteenth-century child-saving movement, or child-rescue as it was also known, that sought to improve the circumstances of orphaned, deserted, mistreated or vulnerable children. At this time, there were numerous societies and charities dealing with the needs of the young; Thomas Barnardo founded his first home for 
children in 1869, as did Thomas Stephenson after talking to children living underneath the arches of Waterloo Station, London. In the same year Maria Rye began sending disadvantaged youngsters to Canada in an attempt to raise them from the poverty of urban England. The presence of the words 'saving' and 'rescue' in the mission statements of many of these charities and in the rhetoric of those who drove them suggests these organisations believed broadly in removing children from undesirable family and environmental situations and shaping them into independent and productive individuals. Rudolf, however, was unlike his child-saving peers. He was particularly suspicious of those who aligned with no particular denomination or religious creed, such as Barnardo who offered a protestant upbringing in non-denominational surroundings. ${ }^{8}$ Rudolf's approach as the manager of a national philanthropic organisation was more cautious than that of his contemporaries. The more controversial Barnardo, for example, actively promoted the action of 'philanthropic abduction', that is removal from the family home or kinship group for the good of the child, an endeavour never endorsed by the WSS. ${ }^{9}$ Also the WSS was distinguished from other child-saving societies by Rudolf's philosophy that the management of the institutional 'homes' that he oversaw was to be devolved to local bodies rather than controlled by the central organisation. Rudolf was clear that the actions of the WSS represented the church in action and not the founder. ${ }^{10}$ By 1902, the WSS had expanded rapidly and was operating ninety homes across the country (including receiving homes in every Anglican diocese) that cared for 3071 children. ${ }^{11}$ The objective of this chapter is not to focus too much on the mechanics of the organisation. Excellent research on it already exists. ${ }^{12}$ Instead it is more concerned with how ideas of the 'perfect' family were forged and presented to children that were under its care and control. ${ }^{13}$

Thus, while the immediate 'improvement' of a child's circumstances was the initial goal of the WSS, its long-term objective was to alter the mentality and habits of the working-class and by extension help to eradicate endemic life-cycle poverty. As F. M. L. Thompson argues, ultimately institutions such as this sought to bring reinforcement to what they saw as a disintegrating and collapsing system which had hitherto ensured social order and stability. ${ }^{14}$ At the heart of this traditional society was the family, therefore, much of the work of this and similar philanthropic organisations was premised on the idea that family structures and domestic bonds between the poor were limited and needed to be 
strengthened. ${ }^{15}$ This has led historians such as Lydia Murdoch to argue that philanthropy adopted a system of cottage homes in order to instil the idea of a respectable 'family' in a constructed and controlled environment. Such an approach served to legitimise removal while undermining the biological structures of working-class households. ${ }^{16}$ Philanthropy, similarly to Poor Law relief after 1834, assumed a didactic role within the broader welfare landscape of the late nineteenth century. ${ }^{17}$ If we accept this premise then it is vital to develop a better understanding of the 'family' that the organisation wanted its young subjects to replicate in their adult lives. While Murdoch and others have explored this approach for other institutions more generally, a new insight can be obtained through examining how the philanthropic ideal was imposed on the children who were admitted to the WSS with some form of physical or mental impairment. In this instance the WSS is particularly useful because it was not a 'sentimental' charity founded specifically to advance the care and needs of the child 'cripple'. ${ }^{18}$ A sample of 300 children that were in the care of the WSS between the years 1881 and 1900 have been distilled from the extant records and is used here to investigate how philanthropists constructed the idea of the family unit and relationships within it. ${ }^{19}$ In this endeavour the 'disabled' child, often thought to be excluded from an independent future, offers a particularly useful lens for constructing family backgrounds, exploring ideas about future adulthood (including future reproductive potential), and social concepts of those who were 'different' to the majority of the population. As well as organisational casefiles, letters written by poor parents to the WSS, and internal documents of the organisation are used to demonstrate how in some situations middle-class 'reformers' engineered the break-up of working-families in order to promote and instil their own perceptions of what a family should look like. At the heart of these efforts was the middle-class belief that 'in order to be saved, children had to be transplanted to a new kind of domestic space'. ${ }^{20}$ The question of what intellectual, scientific, economic, and political influences were prominent in shaping the attitudes of the charitable classes towards working-class families in London and beyond at this point in time is one that requires more attention, both in its own right and for what the answers to such questions tell us about the place of children within working-class families more generally. 


\section{The Nineteenth-Century Context}

Welfare and medical reform were not conceived in a vacuum but shaped by contemporaneous attitudes and discourses over the family that were themselves influenced by numerous ingrained contemporary ideologies in the Victorian period. These are an important backdrop to the mission of the WSS. Religion underpinned, for example, philosophies of separate spheres and domesticity. Imagery portrayed women as the 'angel in the house' and pushed them into the role of moral guardian both of the family and the nation. ${ }^{21}$ The association of women with the home and men with the outside world has led to assumptions that have shaped into the public and private. ${ }^{22}$ The role of the father in Victorian society is much vaguer but it was assumed that the public world was dominated by masculine values of competition and achievement. Victorian fatherhood was bound up in economically providing for the family. ${ }^{23}$ Male working-class parents might well have found it difficult to live up to the standards set by the affluent classes and a mother could not necessarily remain at home. Influential Parliamentary commissions in 1840 and 1844 reported that 'neglectful and incompetent slum parents' were undermining the moral training which children were receiving in Sunday schools. So powerful was the disapproval towards the home and family life of the poor it is not surprising that middle-class reformers sought to actively re-configure families into something more like their own.

More widely, Samuel Smiles published the enormously influential SelfHelp in 1859. Geared towards encouraging its readers towards an independent and prosperous life Smiles argued in Self-Help that 'the spirit of self-help is the root of all genuine growth in the individual'. ${ }^{24}$ It was immensely popular and in its first year sold more than 20,000 copies. By 1904, the year that Smiles died, over a quarter of a million had been sold. By popularising the idea of state intervention or dependence as enfeebling, Smiles' work reached a receptive audience with the British middle-class who were becoming increasingly involved in civic life following the Great Reform Act (1832) and the Poor Law Amendment Act (1834). Self-Help particularly chimed with the ethos and philosophies of the latter legislation which depicted notions of the idle able-bodied man as a drain on ratepayers and society. The focus on individualism was inevitably attractive to those working in public life and the principles were taken and applied to the working-class and poorer elements of the population as part of the Poor Law crusade which began in 1869 and will 
feature in more detail below. Yet these principles were not just imposed through the mechanics of the Poor Law by a dominant middle-class; they were also reworked and adopted by activists from within the aspirational elements of the working-class who invested in the ideal of productive able-bodied men providing for their families. For them the self-help philosophy was intimately embedded within working-class political aspirations for suffrage that took form from the chartists through to the Labour Party. ${ }^{25}$ Thus independence formed 'the bedrock of men's claims to citizenship, countless self-improvement schemes, and were ingrained in working-men's rhetoric about self-respect and independence'. ${ }^{26}$ This subsequently resulted in fathers, and their role in the family as provider, becoming fixed in the wider nineteenth-century discourse associated with self-help and conducting independent lives.

In a curious historical symmetry, Charles Darwin's On the Origin of Species was published on 3 October 1859, the same day as Smiles' SelfHelp. Darwin's text and its ideas about evolution and survival of the fittest requires no introduction and the influence it had on his cousin, Francis Galton, has been well documented. ${ }^{27}$ Prior to Darwin, ideas about degeneration and proto-eugenic discourse were essential elements in redefining ideas about working-families and the environments in which they lived. Galton argued in his work Hereditary Genius (1869) that character traits in humans were transmitted from parent to child. He raised concerns about more 'respectable' classes marrying later in life and having fewer children while the poor and 'undesirable' appeared to be promiscuous and breeding without check. He feared that 'the race gradually deteriorates, becoming in each successive generation less fit for high civilisation'. ${ }^{28}$ In 1883, Galton coined the term Eugenics and initially called for people of above average intelligence to bear more children in order to 'improve' the human race. However, at a national level, the experiences of military defeats in the Zulu War (1879) and the issues surrounding soldier recruitment during the Boer War (1899-1902) meant that relationships between families and the state in the late nineteenth-century were reshaped around ideas of national efficiency and 'improving' the circumstances of the poor. ${ }^{29}$

By 1869, ten years after Self-Help and just as ideas of degeneration were beginning to gain traction, the President of the Poor Law Board, George Goschen, issued a directive that called for greater cooperation between Poor Law Unions and the Charity Organisation Society. Known as the Goschen Minute, it stated that charity should take responsibility 
for those in work that required supplements to wages and that the Poor Law should deal exclusively with those that were truly destitute. The objective was to cut Poor Law expenditure and prevent unscrupulous applicants from among the 'unrespectable' working-poor from claiming simultaneous help from charity and state bodies. At the heart of the Goschen Minute was an attempt to abolish Poor Law out-relief by dealing with those that genuinely required help inside the institutional space of the workhouse. The Charity Organisation Society took up the mantle of investigating poverty and assessing need with the objective of changing the behaviour of individuals living in poverty, while Goschen stressed that the poor should plan for future crises and need through the use of friendly societies, sick clubs, and saving accounts. ${ }^{30}$ In this restructuring of welfare policy that signalled the beginning of the Poor Law crusade against out-relief we observe the infiltration of Self-Help individualism into the management of both state and voluntary bodies designed to relieve those in need. Furthermore, the change in policy also redefined working-families as devious, idle, and dependent and thus they required deterrence and direction for their own benefit by a paternal state.

By the late nineteenth-century the influential discourses of Smiles and Galton, in combination with the actions of Goschen, had broadly redefined perceptions of poor families as a danger to national development. Inevitably they were conceptualised as a threat to the economy, themselves, and society more generally. At its softer end, this train of thinking can be seen as integral to the work of Octavia Hill, the granddaughter of Dr T. Southwood Smith and member of the Charity Organisation Society, who took an interest in improving the homes of poor families. In her most influential work, Homes of the London Poor, she lamented: 'The people's homes are bad, partly because they are badly built and arranged; they are tenfold worse because the tenants' habits and lives are what they are'. ${ }^{31}$ She devoted her life to improving the standard of housing in London and proclaimed 'I feel most deeply that the disciplining of our immense poor population must be effected by individual influence; and that this power can change it from a mob of paupers and semi-paupers into a body of self-dependent workers'. ${ }^{32}$ The influence of self-help ideology and degenerative discourse is undeniably evident here, but also the belief from the 'respectable' elements of society that it was their duty to educate and bring about change in those living at society's margins. In turn, Hill's idea of the family served to reinforce the middle-class ideal of a 'bread-winning' father figure and a domesticated mother, as outlined 
in the overview. The dwellings that she provided were not given as an act of charity but designed to maintain working-class pride and return a profit. She was adamant 'that a working-man ought to be able to pay for his own house'. ${ }^{33}$ It is in this rather gloomy intellectual and social climate that ideas about the family were shaped within the walls of the WSS homes. Children, in their turn, came to be emblematic of the task faced by social leaders. The Poor Law crusade against out-relief created a vacuum in welfare provision that was filled by the 'child-saving' movement spearheaded by figures such as Rudolf, Barnardo, Thomas Stephenson, and Maria Rye. This movement, in combination with the growth of elementary schooling, introduced in 1870 and made compulsory a decade later, made children living in poverty and with mental and physical disabilities more visible and open to public scrutiny and assessment than ever before. ${ }^{34}$ Voluntary organisations, such as the WSS, were in a unique position to manage the needs of these individuals and at the same time directly able to demonstrate the ideals of the family that they wanted to promote. It is to this matter that the chapter now turns.

\section{The Experience of the Waifs and Strays Society}

The children admitted to the care of the WSS were subsequently constructed as the potentially dependent poor. Because their need was often amplified by disability, they were perceived as the individuals most unlikely to break the cycle of generational poverty. When admitted into the care of the WSS each child was accompanied by an application form that included information such as name, age, address, details about parents, date of baptism, schooling, and a testimony of need, usually completed by a prominent person within the local community (often the parish vicar but also middle-class charitable visitors) who knew their domestic circumstances and could attest to their welfare requirements. Cara Dobbing has traced a similar form that was used to provide information on patients when they were first admitted to the asylum, in her chapter for this volume. The data from these applications, alongside internal Waifs and Strays communications, letters to the society from parents/carers/potential employers, and medical assessments will be used to identify how poor families were imagined in the records of the WSS and to explain why children were thought to be better placed in care rather than left in their homes. 
Before the WSS had even opened its doors to the public the influential emigration agent Maria Rye wrote to Rudolf 'to press upon you the importance of making the girls a first point...People will tell you the girls cannot be helped-cannot be found-but this is all nonsense, and they need the help a thousandfold more than the boys'. ${ }^{35}$ There is no evidence of the impact that this letter had on Rudolf-he had never met Rye-but within the work of the WSS we can observe an interesting approach when it comes to gender. Annie Skinner has conducted a quantitative analysis of the whole WSS archive and found that $42.2 \%$ boys and $57.8 \%$ girls were admitted into the organisation. ${ }^{36}$ Within the wider data she identified 270 cases that included the Charity Organisation Society's involvement in the application. In these there was a split of $55 \%$ boys to $45 \%$ girls that suggests a greater concern among the philanthropic class about rectifying the habits of future able-bodied males. ${ }^{37}$ The sample of impaired children used here, however, sees a reverse in the situation with it being made up of $79 \%$ girls (237) and $21 \%$ (63) boys. The core difference between this smaller sample and the wider cohort is, of course, impairment and explanations for why the sample is so heavily weighted towards girls need to be explored.

Within the homes of nineteenth-century working-families female children occupied a unique and vital place. They contributed to the maintenance and cleanliness of the home while providing important childcare duties that provided space for parents to work and boost the domestic economy. ${ }^{38}$ Furthermore, these skills were transferrable which also made girls useful valuable commodities in both the charity home and workplace, with their behaviour considered to be more manageable than that of boys. ${ }^{39}$ In addition, there were persistent fears about the moral fibre and vulnerability of young girls living in close proximity to urban vice and the supervision of their bodies within the respectable domain of the charitable home was considered an important element in preventing the reproduction of bad heredity. If the impairments of the girls within this sample could be ameliorated, managed, or rectified with the aid of philanthropy then future independent workers and respectable mothers might be produced.

By examining the medical conditions that children were living with when entering the care of the WSS (Table 8.1) we can observe that physical impairment and associated conditions were the core issues that the organisation dealt with. Paralysis, missing limbs, disease (most commonly 'hip disease'), physical deformity, and restricted mobility accounted for 
Table 8.1 Medical diagnoses of children admitted to the WSS

\begin{tabular}{lcc}
\hline & Frequency & Percent \\
\hline Mental disability & 33 & 11.0 \\
Impaired eyesight & 22 & 7.3 \\
Paralysis & 24 & 8.0 \\
Deaf & 13 & 4.3 \\
Missing limb & 20 & 6.6 \\
Disease & 29 & 9.6 \\
Malnutrition & 9 & 3 \\
Physical deformity & 110 & 36.6 \\
Restricted mobility & 40 & 13.3 \\
Total & 300 & 100 \\
\hline
\end{tabular}

Source CSA, Waifs and Strays Society Casefiles

almost three quarters $(74.3 \%)$ of the disabled children coming to the WSS. While these might appear debilitating conditions, the records reveal concerted efforts to enable the children to become useful in the work place and be shaped into future independent adults and thus economic supporters of the family. The occupation of tailoring was one that was frequently sought for boys in the care of the WSS. For girls the most frequent occupations were domestic service (21.3\%), machine knitting $(14.7 \%)$, and some were placed in positions as sewing maids, dressmakers, and laundry workers. Some boys were found positions in the merchant navy, pattern shops, and grocery stores. On the whole these were respectable and stable trades that were rarely listed among the occupations of the children's parents. Edward B., for example, entered the care of the WSS at the age of seven in November 1895. ${ }^{40}$ His mother had died from puerperal fever in 1893 leaving five children, four boys and one girl, of which Edward was the eldest. Upon admission he was said to have a deformed knee and hip and he used an orthopaedic boot to help improve his mobility. In March 1905 he was apprenticed to a tailor in Clapham but wrote to the WSS a year later reporting that his orthopaedic boot needed replacing. The WSS responded positively stating 'we must be prepared to help [Edward] B. with his boot' and they wrote to him telling 'him to have done what is necessary'. ${ }^{41}$ A new boot was made and supplied directly to the boy at a cost of $£ 2$ ls $2 \mathrm{~d}$, the monies being paid by the charity. ${ }^{42}$ As a consequence of this support Edward was able to remain in his position and he contacted the WSS again in December 1912 to report that: ' $\mathrm{I}$ am still in the shop tailoring 
and very comfortable in my digs'. In the same letter he reveals that he was still in contact with his siblings and that they would all be together for Christmas. ${ }^{43}$ Although removed from his home Edward's family ties obviously remained part of his life and this suggests that even to the poor, kinship mattered in terms of belonging and continued to provide emotional support.

Despite the supposed low status of the families who had children cared for by the WSS, potential vice or criminality in the domestic background was recorded in only $9.6 \%$ of cases. When there were instances of interaction with the criminal justice system it was not the actions of children, but the adults responsible for them that were recorded. At the most extreme end of the scale were individuals such as Charlotte $\mathrm{H}$. whose mother had died and whose father was executed for the murder of her elder sister. ${ }^{44}$ More often though, criminality referred to lowlevel crime such as proximity to prostitution and examples will feature in the case studies that follow later in this chapter. Contact with the welfare resources of the Poor Law occurred more regularly than criminality, with $23.5 \%$ of children having had some interaction with the state. This is still a relatively low figure that might be a consequence of two factors; firstly, the impact of the Crusade against out-relief that saw the truly destitute managed in workhouses and secondly, a middle-class sentimentality towards children that did not want to see them tarnished with the stigma of pauperisation from a young age.

An exploration of representative case studies helps to build a more detailed picture of how family was represented, within the WSS. Margaret C. was admitted from the home of her aunt in Leeds at the age of seven in September 1889. ${ }^{45}$ She was described as an 'orphan' fit for emigration and was subsequently detained in an Industrial School. ${ }^{46}$ The information included on her casefile makes it immediately apparent that Margaret was not an orphan in a modern sense ${ }^{47}$ Her mother had died from a stroke before her admission but the father was alive and in reasonably close contact with Margaret. It was noted on her admission documentation that he 'greatly' objected to her emigration. ${ }^{48}$ Furthermore, the Industrial School detention order noted that he was a labourer 'who had not been convicted of any offence and seems fairly respectable'. ${ }^{49}$ From the admission documentation a story emerges of the father having little more than an economic interest in the upkeep of the child with decisions about welfare being left to Margaret's aunt who was a widow and made a living through washing and nursing. In many respects, 
Margaret is typical of many of the families in this volume, her home life was fractured through a set of circumstances, in this case death, and her father needed to work to cover her upkeep. A single female within her kinship group took up her care very much in the traditional nurturing role of women within the domestic sphere. It can be argued that in this instance the father fulfilled the popularly perceived masculine role of caring about, rather than for, the child. For the WSS these complicated domestic circumstances proved to be a source of friction. It was the philanthropic belief that the family 'are not at all able to care for her properly' but the aunt proved quite obstinate and, to a certain extent, made life difficult for those who wanted to offer Margaret external assistance. ${ }^{50}$ Miss $S$ Whitehead who completed the admission documentation complained that she was unable to get the child to see a doctor as her aunt wont let her go and her father dose [sic] not seem to have any control over her at all'. ${ }^{51}$ The ties of this family group are evident in the fight they put up to keep the child, but they were unable to prevent Margaret's admission to the St Chads Home and her subsequent emigration to Canada in May 1897. Margaret's lived life highlights the complexities of domestic arrangements and the survival strategies deployed by working-families in the late nineteenth century.

A further example of the WSS imposing their ideals onto the family life of the poor is demonstrated by Clara B., aged nine, and her brother Alfred, who were admitted to the care of the WSS in 1883. Like Margaret they were deemed 'orphans' fit for emigration but in this instance both parents were still alive and in contact with the children. ${ }^{52}$ The father was disabled, having lost both of his feet in an unspecified accident, and it was noted that he was only capable of earning a small sum and was of 'thoroughly drunken in habits'. ${ }^{53}$ The children were, however, living with their mother who had co-habited with another man for a while but was now believed to be a prostitute. Obviously these were far from ideal circumstances in which to raise children, and the mother's occupation in particular provided a cause for concern, even though it was assumed and based on little more than speculation. If the circumstances are considered objectively, it could have been possible that prostitution was the only way to raise the money to feed and clothe her offspring considering the reduced earning capacity of the father, who we have already seen was cast in role of provider within the Victorian ideal. Moreover, the situation takes on a further degree of complexity when towards the end of the admission testimony it was recorded that 
the mother was 'both deaf and dumb'. Unsurprisingly, the WSS quickly concluded that Clara needed to be removed from her family and moved to Canada to start a fresh and more wholesome life. But before these actions could be implemented, the supposedly 'deaf and dumb' mother wrote a letter requesting that her daughter visits her once more before being sent as a child migrant. Mrs B. stated 'I put my signature on the paper and I am very glad that the Lady is going to take her and I hope that she will be a good girl and mind all that is said to her but I should like her to come home and see me before she goes away'. The letter is legible and displays a degree of literacy that would be unexpected in a person said to be 'deaf and dumb'. There is no evidence that it was written by a third party on behalf of the mother. Here we witness an attempt at what might, in the present-day, be called social engineering. The children were healthy and able-bodied, but the family were clearly not 'desirable' and would only act as bad influences on their moral character. The father was drunk, mother potentially a prostitute, and, even if not, she was a lone parent caring for two children with only a meagre income. Interestingly, the mother accepted the intervention of the WSS and she understood and acknowledged the legality of the contract that she had signed, but broader representations of family and home still loom large in her correspondence.

The mother's insistence on seeing the child before departure sparked a discussion within the management of the organisation. For a child to see her biological mother one final time before being sent to Canada does not seem too extreme a request, but the WSS replied that 'we cannot send the child to her, but will if she wishes it get her to write a farewell letter'. For nineteenth-century philanthropy, the breaking of family ties was essential to rescuing children and improving the poor. The family unit was thus deemed a toxic element and the WSS was concerned that the mother may still hold enough influence to sway the child's opinion and disrupt the planned emigration. Sentimentality was denied to poor families in these situations, even if it meant a mother never seeing her child again. Clara was sent to Canada on 23 April 1885 without having final contact. Once settled, rather than excelling in her new surroundings, she was said to be 'getting along only fairly' and consequently demonstrating the child rescuer's argument that emigration was the best way to improve children and working-families as flawed. ${ }^{54}$

Wider societal narratives about working-class families could gain rapid and firm traction. In the case of Mary Jane T. the application form has 
not survived but there is an array of correspondence and other documentation that helps to piece together the child's narrative. ${ }^{55}$ She was admitted to the Harrow Home operated by the WSS in April 1888 and was said to be 'quite deaf' and also visually impaired. ${ }^{56}$ Her father was not in constant employment and earning 'just about as much as will find him in food and lodging and no more'. ${ }^{57}$ All of the children that have been discussed so far have the shared experience of the father not being meeting the self-help expectation of provider that was so central to Victorian mind-sets. Within the admission material there is no mention of the mother. Mary's application was instigated by William Robert Barclay, the vicar of Harrow whose wife had paid $£ 12$ for her care while with the WSS. Rev. Barclay sent a letter to Rudolf in 1889 that stated: 'her father called here lately desiring to know where she was, I told him, also saying that from his dress \& appearance, I judged that he now would be able, and ought to pay for her' ${ }^{58}$ Initially here we see an expectation that the father should provide for his child but not necessarily be responsible for her everyday welfare or well-being. Barclay continued, 'He spent the day with his child, and those who have the care of her, having two meals at their cost and not offering any payment. I now put the matter in your hands, feeling sure that the Society would not wish to release a father from his duties' ${ }^{59}$ Here we see that the time spent with his daughter seems secondary to the fact that he failed to offer any payment for the meals that he consumed while there and his unwillingness to assume the role of provider for his offspring. Family ties come across as unimportant and of little value to the child herself. We have an example of a father trying to act as a parent in the modern sense without any recognition of this fact from the charity. The overwhelming concern was with economics and making sure the father, who appeared to be capable of paying, actually did so. The attitudes displayed by the Rev Barclay resonate with other professional men of the sort analysed by Kim Price in his chapter for this volume.

However, the situation was complicated by the role of the Barclay's as benefactors for the child while she was under the care of the WSS. The following letter, included in full, from Rachel Barclay to Rudolf is revealing:

Dear Sir

Being now nearly 85 years old, feeling my strength decrease, I am reminded that my days are drawing to a close. I have for 6 years paid for 
Mary Jane T (1290) now in the Home here, she will be 11 years old next Jany. I should now prefer paying a sum of $£ 100$ for the support and care of her for the future; rather than a yearly one; while I live I shall take a warm interest in her, and when I am summoned hence by Almighty God I doubt not that my granddaughter Adela Joyce who is the secretary to the Home here will continue it, please do not publish my name in the report, but merely put "a friend". I enclose the money.

Believe me to be yours truly

Mrs Rachel Barclay ${ }^{60}$

There is much to dissect in this correspondence, but we see a substantial amount of money provided for the care of the child in what appears a Dickensian act of kindness. Rachel Barclay explicitly stated that the money was intended for Mary Jane $T$. but there was some ambiguity over whether the money should be transferred to the child if she was to leave the care of the WSS, a situation that Rudolf quickly sought to clarify. Writing after the death of her grandmother, Adela Joyce replied to the WSS:

... we believe that her intention was that the whole of the money should be given to the Society. She never said anything quite definite on the subject, but we believe that this was her wish and that she did not intend any surplus which may be left over to be given to Mary T. ${ }^{61}$

Thus while the child was supported by a wealthy benefactor this was only while she remained in the charge of a respectable organisation such as the WSS. Here the biological family of the child were thus side-lined and even when the father attempted to fulfil a paternal role he was chided for his failure to adequately provide for the child or himself. Following the investment of Rachel Barclay he also retreated into the background of the organisation's thinking and ultimately Mary Jane was put out to service in 1891 eventually moving to Cheshire to "better" herself. It is unclear how much of the $£ 100$ was spent on her care and well-being.

A final case study emblematises the wider arguments of this chapter. Charles R. was eleven-years-old when admitted to the charity from his home in Lowestoft in $1886 .{ }^{62}$ Here we see why the term impairment is better suited than disability - he was said to be lame and blind of one eye. He goes about with a crutch with great rapidity and is full of spirit. Very intelligent, fond of reading, generally at the head of his class 
very anxious to be "a good scholar" in order to earn a living...very bad home influences' ${ }^{63}$ Charles was, however, at risk because 'his lameness is owing to the neglect of his mother and $\underline{I}$ am told the loss of his eye came from her carelessness'. ${ }^{64}$ We therefore encounter a good (albeit in their view impaired) child in a bad family and one ripe for removal. The rhetoric, however, does not match up to the reality if we dig a little deeper. Question 17 of the application form asked 'Has he ever attended day school?' The answer is 'has attended as a rule all his life'. This was still a time when the nature of compulsory schooling was contested by working-people and therefore his presence and success in school must have been with parental support. ${ }^{65}$ Furthermore, the application notes that 'his mother would pay something for his support'. Perhaps she recognised his impairments and that the best way to secure an apprenticeship would be with the support of the charity. He was admitted to the St Nicholas Home for crippled children where we lose track of his journey after a couple of years.

\section{CONCLUSION}

Victorian philanthropists made little or no attempt to understand workingclass family structures and the cultures that transcended their own ideals of what constituted 'the family unit'. Instead they sought to shape the lived experiences of poor children into something acceptable to the middle-class ideal of family. Socialisation of removed children sought to re-educate these young minds into a set of expected and accepted forms of behaviour. Influenced by the ideas of Samuel Smiles, the WSS and its sponsors believed that families should be hardworking and thriftful and where (as often) this was not the case individual families and family members were constructed as neglectful, harsh, obstinate, uncaring and interested in gratification through base senses while doing material and moral harm to children. ${ }^{66}$ Inside philanthropic institutions for children the idea of the family was consequently re-imagined into what a respectable working-family should look like and linked firmly with ideas of domesticity and responsible citizenship. In many cases, as we have seen through the life-stories analysed in this chapter, this re-imagining involved the retrospective elimination of family ties; the absence of parents in admission documents is evident even though less than a third of children admitted were orphans. ${ }^{67}$ For many philanthropic actors, the separation of children from their family was essential if such children 
were to be reconfigured and fashioned into responsible citizens and consequently mothers and fathers. In turn, the homes provided by the WSS were designed for the poor who could not easily be improved, the truly undeserving in the eyes of charity, and the best hope for change was breaking the cycle of poverty and eradicating what were considered dysfunctional family units. Parents and extended family became a danger to the development of youngsters and from the records of the WSS we acquire a sense of the emphasis on making the children independent and productive in their future lives regardless of impairment or disability.

These broad themes arising out of a study on the WSS matter for the wider agenda of this volume in three ways. First, they confirm the sense of Steven King and Iain Riddell in their chapters that the shape and meaning of 'family' were essentially imagined, by those from within and those from without kinship and fictive kinship groups. Ties of blood, law or contract were powerful, but over the long term such ties could be disrupted by changing individual relationships or, as in the case of intervention by philanthropists, by a re-working of families from outside. Secondly, while Geoff Monks, Regina Poertner, Iain Riddell, Steven King, Kim Price and others point forcefully to the reconfiguration of family forms, meanings and boundaries by events such as re-marriage, deaths, or illegitimate births, this chapter introduces a new and powerful late nineteenth-century force in the engineering of family, the philanthropist and the institution. This chapter, in other words, changes the focus from forces working within the family to those working from without. Finally, while the focus of this work on the WSS has clearly been on the long-term removal of children, particularly children with impairments, from the family context, there is also much underlying evidence for the continuing power of family ties. Parents did not always meekly give up their children, just as families did not always or usually lose touch with relatives who ended up in the Garlands Lunatic Asylum that is the focus of Cara Dobbing's chapter for this volume. The fact that some children were spirited away in an underhand fashion also speaks to the sense that, for the most ordinary of families, ties of emotion and belonging are more important in locating the meaning of the Victorian family than are simple calculations of size and structure.

Acknowledgements The research for this chapter would not have been possible without the help of Ian Wakeling and the archives team at the Children's Society, and the financial support of the Wellcome Trust, WT108624MA. I would 
also like to thank the editors of this volume for their thought-provoking and insightful comments, and both Dr Annmarie Valdes and Alyssa Stevenson for reading earlier drafts of the chapter.

\section{Notes}

1. C. Nelson (2007) Family Ties in Victorian England (Westport: Praeger), p. 145.

2. Quoted in ibid.

3. G. Frost (2008) Living in Sin: Cohabiting as Husband and Wife in Nineteenth-Century England (Manchester: Manchester University Press); G. Sims (1889) How the Poor Live and Horrible London (London: Chatto \& Windus), p. 37. The papers which form this book were originally published in The Pictorial World and The Daily News.

4. S. Koven and S. Michel (1993) Mothers of a New World: Maternalist Politics and the Origins of Welfare States (London: Routledge); S. Koven (2004) Slumming: Sexual and Social Politics in Victorian London (Oxford: Princeton University Press); K. Ittman (1995) Work, Gender and Family in Victorian England (Basingstoke: Macmillan Press); and C. Lee (2012) Policing Prostitution, 1859-1886: Deviance, Surveillance and Morality (London: Pickering \& Chatto).

5. L. Bland (1995) Banishing the Beast: English Feminism and Sexual Morality 1885-1914 (London: Penguin Books); B. Schillace (2013) "Curing "Moral Disability": Brain Trauma and Self-Control in Victorian Science and Fiction', Culture, Medicine, and Psychiatry, 37:4, pp. 587600; V. Heggie (2008) 'Lies, Damn Lies, and Manchester's Recruiting Statistics: Degeneration as an "Urban Legend" in Victorian and Edwardian Britain', Journal of the History of Medicine and Allied Sciences, 63:2, pp. 178-216.

6. See the essays included in P. Mandler (ed.) (1990) The Uses of Charity: The Poor on Relief in the Nineteenth-Century Metropolis (Philadelphia: University of Pennsylvania Press); also P. Shapely (2000) Charity and Power in Victorian Manchester (Manchester: Chetham Society); and R. Humphries (1995) Sin, Organized Charity and the Poor Law in Victorian England (Basingstoke: Macmillan).

7. The preservation of the Children's Society Archive with support from the Wellcome Trust has opened new avenues to explore the past of experiences of children and allows deeper insights into lived experiences of both individuals and families.

8. J. Stroud (1971) Thirteen Penny Stamps: The Story of the Church of England Children's Society (Waifs and Strays) from 1881 to the 1970 s (London: Hodder and Stoughton), p. 30. 
9. J. Parr (1980) Labouring Children: British Immigrant Apprentices to Canada, 1869-1924 (London: Croom Helm).

10. P. Higginbotham (2017) Children's Homes: A History of Institutional Care for Britain's Young (Barnsley: Pen and Sword), p. 106; J. Stroud, Thirteen Penny Stamps, p. 44.

11. J. Stroud, Thirteen Penny Stamps, p. 52.

12. See A. Skinner (2015) "Voices of the Visitors": An Exploration of the Work of the Charity Organisation Society in Oxford, 1878-1880', Midland History, 40:1, pp. 74-94; A. Skinner and N. Thomas (2018) “"A Pest to Society": The Charity Organisation Society's Domiciliary Assessments into the Circumstances of Poor Families and Children', Children \& Society, 32, pp. 133-144; L. Jackson (2000) Child Sexual Abuse in Victorian England (London: Routledge); and H. Ward (1990) 'The Charitable Relationship: Parents, Children and the Waifs and Strays Society' (Unpublished PhD thesis, University of Bristol).

13. See F. M. L. Thompson (1981) 'Social Control in Victorian England', The Economic History Review, 34:2, pp. 189-208.

14. Ibid., p. 206.

15. L. Murdoch (2001) 'From Barrack Schools to Family Cottages: Creating Domestic Space for Late Victorian Poor Children', in J. Lawrence and P. Starkey (eds.) Child Welfare and Social Action in the Nineteenth and Twentieth Centuries: International Perspectives (Liverpool: Liverpool University Press), pp. 147-173, p. 158.

16. Ibid., p. 161.

17. M. Doolittle (2009) 'Fatherhood and Family Shame: Masculinity, Welfare and the Workhouse in Late Nineteenth-Century England', in L. Delap, B. Griffin, and A. Wills (eds.) The Politics of Domestic Authority in Britain Since 1800 (Basingstoke: Palgrave Macmillan), pp. 84-110, p. 93.

18. It did interact with organisations such as the Invalid Children's Aid Association, so that it might provide the best care and, where possible, treatment for the young. For more on orthopaedic charities, see A. Borsay (2006) 'Disciplining Disabled Bodies: The Development of Orthopaedic Medicine in Britain, c. 1800-1939', in D. Turner and K. Stagg (eds.) Social Histories of Disability and Deformity (Abingdon: Routledge), pp. 97-116.

19. Orphan was a subjective term and open to interpretation for more, see L. Murdoch (2006) Imagined Orphans: Poor Families, Child Welfare, and Contested Citizenship in London (New Brunswick: Rutgers University Press); L. Peters (2000) Orphan Texts: Victorian Orphans, Culture and Empire (Manchester: Manchester University Press).

20. Murdoch, 'From Barrack Schools to Family Cottages', p. 151. 
21. E. Gordon and G. Nair (2003) Public Lives: Women, Family and Society in Victorian Britain (New Haven and London: Yale University Press), p. 3.

22. Ibid.

23. J. M. Strange (2012) 'Fatherhood, Providing, and Attachment in Late Victorian and Edwardian Working-Class Families', Historical Journal, 55:4, pp. 1007-1027, pp. 1008-1011; Doolittle, 'Fatherhood and Family Shame'.

24. S. Smiles (1859) Self-Help; With Illustrations of Character and Conduct (London: John Murray), p. 1.

25. Doolittle, 'Fatherhood and Family Shame', p. 90.

26. Strange, 'Fatherhood, Providing, and Attachment', p. 1011.

27. S. J. Taylor (2017) Child Insanity in England, 1845-1907 (London: Palgrave Macmillan), pp. 38-40.

28. F. Galton (1869) Hereditary Genius (London: Macmillan).

29. S. J. Taylor (2018) 'Becoming Canadian Adults: British Childhood Emigration to Canada in the Late 19th Century', in J. Baxter and M. Ellis (eds.) Nineteenth Century Childhood in Interdisciplinary and International Perspectives (Oxford: Oxbow Books), pp. 63-75, p. 65; Doolittle, 'Fatherhood and Family Shame', p. 86; M. Jackson (2003) "Grown-Up Children": Understandings of Health and Mental Deficiency in Edwardian England', in M. Gijswijt-Hofstra and H. Marland (eds.) Cultures of Child Health in Britain and the Netherlands in the Twentieth Century (Amsterdam: Rodopi), pp. 149168, p. 151 .

30. E. Hurren (2007) Protesting About Pauperism: Poverty, Politics and Poor Relief in Late-Victorian England, 1870-1900 (Woodbridge: Boydell \& Brewer); Skinner, 'Voices of the Visitors', p. 77.

31. O. Hill (1875) Homes of the London Poor (Republished by London: Routledge in 2016), p. 10.

32. Ibid., p. 25.

33. Ibid., p. 18. For context see Doolittle, 'Fatherhood and Family Shame', pp. 85-89.

34. L. McCoy (1998) 'Education for Labour: Social Problems of Nationhood', in G. Lewis (ed.) Forming Nation, Framing Nation (London: Routledge), p. 121; W. B. Stephens (1998) Education in Britain, 1750-1914 (Basingstoke: Macmillan); and Taylor, Child Insanity, pp. 139-148.

35. Quoted in Stroud, Thirteen Penny Stamps, p. 33, original emphasis; for more on Maria Rye, see, M. Diamond (1999) Emigration and Empire: The Life of Maria S. Rye (New York: Routledge).

36. A. Skinner (2017) 'Reasons for Rescuing Orphans, Destitute, Neglected or Imperilled Children: Analysis of the Waifs and Strays Society in the Late Nineteenth Century', Scottish Journal of Residential Child Care, 16:3, p. 5. 
37. Skinner and Thomas, 'A Pest to Society', p. 136.

38. Taylor, Child Insanity, p. 83; D. Wright (1998) 'Familial Care of "Idiot" Children in Victorian England', in P. Horden and R. Smith (eds.) The Locus of Care: Families, Communities, Institutions, and the Provision of Welfare Since Antiquity (London: Routledge), pp. 176-198.

39. J. Melling, R. Adair, and B. Forsythe (1997) "“A Proper Lunatic for Two Years": Pauper Lunatic Children in Victorian and Edwardian England. Child Admissions to the Devon County Asylum', Journal of Social History, 31:2, pp. 371-405.

40. Children's Society Archive (hereafter CSA), WSS Casefiles, Edward B, $\mathrm{CF} / 05062 / 1-3$.

41. CSA, Edward B., CF/05062/95.

42. CSA, Edward B., CF/05062/97.

43. CSA, Edward B., CF/05062/14.

44. CSA, WSS Casefiles, Charlotte H., CF/002270.

45. CSA, WSS Casefiles, Margaret C., CF/021312/4.

46. CSA, Margaret C., CF/021312.

47. Murdoch, Imagined Orphans; Peters, Orphan Texts.

48. CSA, Margaret C., CF/021312/5.

49. CSA, Margaret C., CF/021312/6.

50. CSA, Margaret C., CF/021312/5.

51. CSA, Margaret C., CF/021312/6.

52. CSA, WSS Casefiles, Clara B., CF/000126.

53. CSA, Clara B., CF/000126/2.

54. For more on emigration experiences see Taylor, 'Becoming Canadian Adults'.

55. CSA, WSS Casefiles, Mary Jane T., CF/001290.

56. CSA, Mary Jane T., CF/001290/3.

57. Ibid.

58. CSA, Mary Jane T., CF/001290/6.

59. Ibid.

60. Ibid.

61. CSA, Mary Jane T., CF/001290.

62. CSA, WSS Casefiles, Charles R., CF/000716.

63. CSA, Charles R., CF/000716/1-2, Original emphasis.

64. Ibid.

65. H. Cunningham (1995) Children and Childhood in Western Society Since 1500 (London: Longman), p. 102.

66. Thompson, 'Social Control in Victorian England'.

67. Murdoch, Imagined Orphans. 
Open Access This chapter is licensed under the terms of the Creative Commons Attribution 4.0 International License (http://creativecommons.org/licenses/ by $/ 4.0 /$ ), which permits use, sharing, adaptation, distribution and reproduction in any medium or format, as long as you give appropriate credit to the original author(s) and the source, provide a link to the Creative Commons license and indicate if changes were made.

The images or other third party material in this chapter are included in the chapter's Creative Commons license, unless indicated otherwise in a credit line to the material. If material is not included in the chapter's Creative Commons license and your intended use is not permitted by statutory regulation or exceeds the permitted use, you will need to obtain permission directly from the copyright holder.

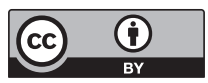

